\title{
Managers' expectations, business cycles and cartels' life cycle
}

\author{
Carmen García ${ }^{1}$ (1) - Joan Ramon Borrell ${ }^{2,3}$ (1) . \\ José Manuel Ordóñez-de-Haro ${ }^{4}\left[\begin{array}{c}\text {. Juan Luis Jiménez } \\ 1\end{array}\right.$
}

Accepted: 1 February 2022 / Published online: 21 February 2022

(c) The Author(s) 2022

\begin{abstract}
The literature presents mixed findings regarding the economic conditions under which cartels form and collapse, and regarding how stable they are across firm-specific and industry-wide business cycles. The relationship between cartel life cycles and business cycles has been insufficiently analyzed to date. In this paper, we study in depth whether collusion is pro-cyclical or counter-cyclical. We analyze the relationship between cartel start-ups/break ups and economic cycles using a dataset of sanctioned cartels by the European Commission (EC) that were active between 1997 and 2018, after the leniency program had already been introduced. We also double check whether this relationship has changed with respect to the pre-leniency period from 1991 to 1996 . Our results show that cartels are more likely to be formed when the business has evolved positively in the previous months, and cartels are less likely to collapse when the business has evolved positively, and managers expect prices to decline. The EC's sanctioning activity has been an effective deterrent and has had a destabilizing effect on cartels. However we found no evidence that managers' expectations on prices affect cartel formation. All these results are an important issue for anti-cartel policy enforcement since knowing when cartels are more prone or less likely to occur would help authorities prevent their formation or their early detection.
\end{abstract}

Keywords Cartels · Business cycles · Business expectations, Antitrust

JEL classification $\mathrm{D} 7 \cdot \mathrm{K} 2 \cdot \mathrm{L} 4 \cdot \mathrm{O} 4$

Juan Luis Jiménez

juanluis.jimenez@ulpgc.es

Extended author information available on the last page of the article 


\section{Introduction}

Cartels are illegal and, if discovered, their members are punished under competition laws in most jurisdictions. This makes cartels very secretive in nature and means they use increasingly sophisticated means of coordination and communication to avoid being discovered. Thus, despite recent improvements that have strengthened the ability of antitrust authorities to combat cartels, successfully detecting, prosecuting, and sanctioning these illegal practices remains a very difficult task.

Economic analysis can play a fundamental role in providing theoretical and empirical studies that may support authorities in their efforts to detect and prosecute cartels. The use of collusive indicators and modern market screening techniques are particularly helpful in identifying industries that require close monitoring and further investigation (Harrington, 2008).

We aim to contribute to a better understanding of the conditions under which cartels are most likely to occur by empirically analyzing the relationship between cartel life cycles and business cycles. This is an important issue for anti-cartel policy enforcement, since knowing whether cartels are more or less likely during economic booms or recessions would help authorities prevent their formation; or at least facilitate their early detection.

The theoretical literature has extensively studied the relationship between collusion and business cycles, ${ }^{1}$ reaching conflicting conclusions about the phase of the business cycle in which it is easier or more difficult to maintain collusion (see, for instance, Bagwell \& Staiger, 1997; Fabra, 2006; Haltiwanger \& Harrington, 1991; Paha, 2017; Rotemberg \& Saloner, 1986).

The lack of theoretical consensus on this topic has led to a stream of empirical studies that have attempted to assess the applicability and validity of the different theoretical predictions. However, the existing empirical evidence is also mixed, as there is evidence supporting both pro-cyclical and countercyclical collusion (see, for instance, Ellison, 1994; Gallet, 1997; Hyytinen et al., 2011; Rosenbaum \& Sukharomana, 2001; Suslow, 2005). Furthermore, other recent studies (Levenstein \& Suslow, 2011, 2016) that specifically analyze the determinants of cartel births and deaths do not find a statistically significant effect of business cycles on cartel stability. Therefore, the answer to whether collusion is pro-cyclical or contra-cyclical is a controversial and still unsettled question.

The main purpose of our paper is therefore to provide further empirical evidence that helps clarify this question. Unlike most previous empirical studies that are based on case studies, our analysis is based on data and information collected on all the European Commission's (EC's) sanctioning decisions in cartel cases to 2018. We focus on both the formation and the breaking up of cartels, and how these two events relate to economic cycles.

In order to capture the effects of activity cycles, we examine the impact of several variables: the production of the sector, that seeks to represent industry-wide

\footnotetext{
1 For a revision of this literature, see Levenstein and Suslow (2006, 2014).
} 
dynamics; the managers' perceptions of firms operating in the corresponding sector on the evolution of their business in recent months, which can be considered as a proxy to firms' perceived market dynamics; and these managers' price expectations. We make use of European Union (EU) business surveys to gather information on managers' perception of their firms' business evolution and their price expectations. The availability of data for real production at the European level of the different sectors has finally meant that our empirical analysis focuses on the period 1991-2018.

Our empirical strategy employs Poisson model estimations, which allow us to evaluate the effects of the variables capturing business cycles, as well as the EC's sanctioning activity, on the number of cartels formed and on the number of cartels that break up for internal reasons in the EU every month, mostly after the introduction of the leniency program (1997-2018), but also during the pre-leniency period, ranging from 1991 to 1996.

The main results show that cartels are most likely to be formed during firms' upturns, when managers consider that their production level has evolved positively in the previous three months (i.e. growing firms). Results also show that cartels are less likely to collapse when managers consider that their firm's production has evolved positively in the previous months and when they expect a decrease in prices in the near future. Furthermore, the total number of cartels sanctioned by the EC, by increasing the perceived probability of firms being caught, constitutes an effective deterrent against the formation of cartels and a destabilizing factor that promotes the break up of existing ones.

As with any study that relies on data for discovered cartels, our estimates could be biased because the population of discovered cartels might not be a representative sample of the total cartel population (discovered and undiscovered). Several papers in the literature have looked at what the discovered cartels may tell us about the underlying cartel population (Harrington \& Chang, 2009, 2015; Harrington \& Wei, 2017). The bias associated with the use of data from discovered cartels could cause either an overestimation or an underestimation of the effects of the business cycles on the formation and break up on the underlying cartel populations. ${ }^{2}$ Albeit under certain conditions the extent of bias may be modest, our results are not biased with respect to the discovered cartels but should be treated with caution when analyzing the unknown underlying cartel population.

To the best of our knowledge, this is the first empirical study to include managers' perceptions on the recent evolution of their firms' business, as well as the sale price expectations of these managers for the near future, as explanatory variables of the formation and break up of cartels. ${ }^{3}$

After this brief introduction, the second section contains a literature review and also highlights our main contributions in respect to the existing empirical literature. The data is described and discussed in Sect. 3. Section 4 details the empirical strategy, before the results are analyzed in Sect. 5. Section 6 offers a wide range

\footnotetext{
${ }^{2}$ We will discuss this question later in the next section.

3 For a related literature on how expectations affect firms' decisions to engage in white collar crimes, see Simpson and Rorie (2016).
} 
of robustness checks. Finally, the main conclusions of this work are discussed in Sect. 7.

\section{Literature review}

The classic article by Stigler (1964) highlights the key obstacles firms face in reaching and sustaining a collusive agreement. Basically, firms must agree and coordinate on a joint profit-maximization policy, detect deviations from the agreement and enforce the agreement by credible threats to punish deviators. Successful collusion requires that the expected profit from colluding today outweighs the expected profit of deviating from the collusive agreement. In a dynamic approach, the stability of cartel agreements would critically depend on the degree of impatience of cartel members (see, among others, Levenstein \& Suslow, 2016; Tirole, 1988 and an overview of this issue and further explanations).

There are many factors that affect the formation and sustainability of collusion, including those related to changes in market conditions resulting from business cycles. Shocks to short-term demand have significant implications for collusion. Fluctuations in demand and the degree of information that firms have on these fluctuations affect conditions under which collusion is sustainable.

The literature that relates business cycle and cartels predominantly focuses on the stability of cartels instead of cartel start-ups or break ups. The effect of business cycles on cartel duration and collusive pricing has been studied from a theoretical and empirical point of view, although conclusions are mixed.

From a theoretical perspective, there are several pioneering works linking business cycles and collusion. In a seminal theoretical study, Green and Porter (1984), for example, show that it is more difficult to sustain collusion when demand fluctuations are not directly observable by firms, as firms cannot determine whether the low demand is because of a negative demand shock or because another party deviated from the cartel agreement. In this context of demand uncertainty, it is observed shifts between collusive and competitive prices along the collusive equilibrium path. Price war periods, (i.e. during reversions to the non-cooperative outcome), would not reflect cartel break ups but are part of a mechanism cartels use to achieve stability (Levenstein \& Suslow, 2006).

Rotemberg and Saloner (1986) provide an alternative theory of price wars based on demand fluctuations. In their model, firms only observe the demand each period, so that firms might base their future expectations on the current state of demand. They assume that the level of demand is determined each period from independent and identically distributed (hereinafter, iid) shocks. This assumption implies that the current state of demand does not affect expectations of future demand. Consequently, the expected future benefits of collusion (or punishment) are the same regardless of the current demand. Nevertheless, the greater the current demand, the greater will be the gains of deviating from the collusive agreement, and hence the greater firms' incentives to deviate. Collusion is then harder to support in booms, when demand is high, and firms may find it optimal to price counter-cyclically to 
sustain the collusive arrangement. ${ }^{4}$ This conclusion in some ways contrasts with Green and Porter (1984) theory where price wars occur in recessions, when demand is low.

Haltiwanger and Harrington (1991) consider a model with a deterministic cyclical demand that allows for both the level of current demand and firms' expectations on future demand to change over time. These authors conclude that while the gain of deviating from a collusive agreement is greatest during booms, firms find it even more difficult to collude during recessions, as the forgone profits from inducing a price war are relatively low. Therefore, in contrast to the finding of Rotemberg and Saloner (1986), collusion is pro-cyclical: more difficult in recessions, easier in booms.

Rotemberg and Saloner's (1986) and Haltiwanger and Harrington's (1991) models differ with respect to the dynamics of the business cycle, obtaining mixed results, depending on their respective assumptions: when booms and busts come from iid processes, collusion is countercyclical; but, when business expansions and downturns have some correlation over time, collusion is pro-cyclical.

Bagwell and Staiger (1997) consider an extension of the model of collusive pricing consisting of assuming that demand movements are stochastic and persistent. ${ }^{5}$ In their model, a Markov process determines the transition between states of slowgrowth (recessions) and fast-growth (booms). They show that collusive pricing is weakly pro-cyclical (counter-cyclical) when demand growth rates are positively (negatively) correlated through time. ${ }^{6}$

Staiger and Wolak (1992) consider a variation of the model of Rotemberg and Saloner, with the introduction of endogenous capacity constraints. ${ }^{7}$ Firms must first choose capacities at the beginning of each period before demand shocks are realized, and they set prices only after the demand level is known. Staiger and Wolak (1992) find that periods of low demand can lead, through the emergence of excess capacity, to a breakdown of collusion and the outbreak of price wars. They show that price wars are more severe the greater the excess capacity associated with low demand. Conversely, the higher the realized demand in a period, the closer colluding firms will operate to their respective capacity levels and the lower the current gains from deviating from the collusive price; strengthening firms' ability to maintain the collusive pricing.

\footnotetext{
${ }^{4}$ Rotemberg and Saloner (1986) refer to these lowering prices during booms as price wars, although these price wars are not periods of reversion to the non-cooperative solution as in Green and Porter's (1984) model, but rather represent periods of less effective collusion.

${ }^{5}$ Athey and Bagwell (2001) study a model of collusion in which firms receive an iid cost shock, and Athey and Bagwell (2008) analyze a model of collusion in which the cost shock is persistent. However, business cycles are not considered.

${ }^{6}$ They also note that the empirical evidence is mixed since there is both evidence for pro-cyclical (see, for instance, Domowitz, Hubbard and Petersen, 1986a, 1986b, 1988) and countercyclical price-cost margins (see, for instance, Bils, 1987 and Rotemberg and Woodford, 1991).

${ }^{7}$ Capacity constraints can potentially affect firms' incentives to collude in two countervailing ways. First, capacity constrained firms can have less incentives to deviate from collusion as the gains from doing so are limited. Second, capacity-constraints can reduce firms' power to respond to deviations from collusion; increasing firms' incentives to deviate.
} 
Fabra (2006) points out that Staiger and Wolak's (1992) analysis omits that capacity constraints also affect the future losses of deviating from the collusive agreement through their impact on firms' retaliation power. Extending the Haltiwanger and Harrington (1991) model by adding symmetric exogenous capacity constraints, she shows that when capacity constraints are severe enough, the effect of demand fluctuations on the value of future punishment profits is greater than its impact on the value of the foregone collusive profits, so that periods of expanding demand may lead to lower losses from cheating even as collusive profits are increasing, and thus firms find it more difficult to collude during booms; whereas the contrary is true when capacity constraints are not severe enough.

Knittel and Lepore (2010) extend the model of Fabra (2006) by endogenizing firms' choice of capacities, which permits that capacities can also be asymmetric. They identify two types of price wars concerning collusive pricing patterns: severe mixed price wars, when firms revert to non-cooperation in demand periods where at least one firm undercuts the other in equilibrium; and mild price wars, consistent with Rotemberg and Saloner's (1986) theory, when firms price counter-cyclically to maintain collusion. They also find that the most-collusive pricing predictions depend on the level of marginal cost of capacity. If the marginal cost of capacity is high (low) enough, holding current demand constant, prices during booms are generally lower (higher) than in recessions. ${ }^{8}$

Paha (2017) develops a dynamic model, resulting from combining the Besanko and Doraszelski (2004) and Fershtman and Pakes (2000) models, with demand shocks and firms simultaneously deciding their prices and capacity investments in every period. He shows that the incremental value of collusion ${ }^{9}$ increases when firms face a negative demand shock by relaxing capacity constraints and particularly when they cannot reduce capacities quickly, the decline in demand is pronounced, and when it occurs within a short period of time; suggesting that cartel formation is more likely to exist in those circumstances.

The existing empirical evidence regarding collusion and business cycles is also mixed and inconclusive, as studies have found support for both pro- and countercyclical collusive pricing. Porter (1983) analyzes an US railroad cartel which operated in the 1880's on the Chicago-East Coast route, known as the Joint Executive Committee (JEC), to test the existence of switches between collusive and non-cooperative behavior (i.e. price wars) and if these switches are consistent with Green and Porter's (1984) equilibrium. His time-series evidence shows that these switches occurred in the JEC, but does not identify what the causes of these switches were.

Ellison (1994) reexamines the JEC's experience to assess the applicability of Green and Porter's (1984) and Rotemberg and Saloner's (1986) theories. He estimates several dynamic models based on that of Porter (1983) to study the causes of price wars, the cyclical nature of pricing behavior, and the possibility that secret price cuts could have occurred. His empirical evidence provides some support for

\footnotetext{
${ }^{8}$ If the marginal cost of capacity is in an intermediate range of values, no such general pricing patterns can be established.

9 The difference between the collusive value of one firm and its competitive value.
} 
the predictions of the Green and Porter model, although their collusive equilibrium strategies are not clearly identified. Their estimates suggest that unanticipated demand shocks, leading to unusually low demand for one firm, would trigger a price war.

Borenstein and Shepard (1996) use panel data based on US retail gasoline margins in 43 cities from 1986 to 1991 to empirically test the theoretical predictions from the Haltiwanger and Harrington (1991) and Rotemberg and Saloner (1986) models. Their estimates support Haltiwanger and Harrington's predictions: margins are higher when next-period demand is expected to increase, than when it is expected to decline. ${ }^{10}$

Gallet (1997) estimates the effects of domestic demand fluctuations, driven by market demand and/or import supply fluctuations, on oligopoly coordination in the US steel industry from 1950 to 1988 . He shows that the degree of coordination among US steel producers was countercyclical, suggesting that coordination is weakest when market demand is high and import supply is low. His empirical results therefore lend support to Rotemberg and Saloner's (1986) theory.

Galeotti and Schiantarelli (1998) use data on 19 U.S. industrial sectors over the period 1949-1987 to estimate their dynamic structural model. They show that price-cost margins are negatively related to the current state of demand and positively related to expected future demand. Their results are consistent with the theoretical predictions provided by the Bagwell and Staiger (1997) and Haltiwanger and Harrington (1991) models.

Rosenbaum and Sukharomana (2001) use data from the U.S. Portland cement industry over the period 1972-1989 to test Haltiwanger and Harrington's (1991) predictions. The empirical results show that for a given level of output, ceteris paribus, price is lower in the bust part of the cycle than in the boom, which supports Haltiwanger and Harrington.

Hyytinen et al. (2011) use a hidden Markov model, which consists of a hidden process (the industry cartel dynamics in this case, since there may be industries that are never investigated or convicted) and an observation process that reveals information on the state of the hidden process for certain periods (what the researcher knows about the state of the industry in a given period). They find that the chance of forming a cartel is around $20 \%$, increases over their sample period, and responds to positive shocks to GDP, and is therefore pro-cyclical. ${ }^{11}$

Suslow (2005) uses an empirical model to test for the importance of demand uncertainty and cartel organizational characteristics in determining cartel duration. She finds that economic uncertainty, measured as the fluctuation of an industrial production index, accounts for most of the variance in the duration of the

\footnotetext{
10 Similarly, Perdiguero (2010) considers Haltiwanger and Harrington's (1991) model to assess if the Spanish retail gasoline market fits with tacit collusion equilibrium. Using two stage least squares estimations, his results show a positive relationship between current margins and demand expectations, and strengthens his prediction that firms' strategic behavior coincides with a tacit collusion price strategy.

11 They analyze a dataset of legal Finnish manufacturing cartels in the period 1951-1990. This may create a source of selection bias as while illegal cartels have reasons to remain hidden, legal cartels do not.
} 
cartel agreements. Both economic recessions and increased economic volatility have destabilizing effects on cartels.

Levenstein and Suslow (2011) also analyze the impact of cartel organizational features, as well as macroeconomic fluctuations and industry structure, on cartel duration. They find that firm-specific measures of impatience are systematically related to cartel break up. However, they do not find a statistically significant effect of business cycles. In a later work (Levenstein \& Suslow, 2016), these authors find a positive relationship between market interest rates and probability of cartel break up, which is an outcome that they did not find for the international cartels analyzed in their previous work. In this work, they neither find a significant relationship between cartel stability and business cycles.

Table 1 summarizes the mixed findings of the literature regarding the relationship between collusion and business cycles.

As seen above, theoretical papers come to different conclusions regarding the relationship between collusion and business cycles, and the findings of the empirical literature is also mixed. There is a gap in the literature concerning the extent to which, and in which circumstances, collusion is pro-cyclical or counter-cyclical.

Our paper contains a number of elements that distinguish it from most previous empirical studies. First, we use a newly created dataset containing information on all the EC's sanctioning decisions in cartel cases over a period spanning almost 30 years; specifically between 1991 and 2018. Second, we focus on the relationship between cartel formation/break up and economic cycles to determine the cyclical nature of collusion. Third, to make our empirical analysis closer to firms' specific dynamic incentives to engage in a cartel agreement and to break an existing one in response to activity cycles, in addition to variables standing for industrywide dynamics, we pioneer the use of business cycle variables that capture market dynamics as perceived by firms as well as their price expectations. Fourth, we use the Poisson regression model to explore the effects of the aforementioned business cycle variables on the number of cartels that were formed and that internally broke up in any month from 1997 to 2018; a period in which the EC leniency program was in effect. We also double-check whether our results are robust by comparing them with the pre-leniency period from 1991 to 1996. And fifth, unlike other previous empirical works that also analyze the impact of economic cycles on the birth and death of cartels, we do find statistically significant effects of some business cycle variables on the formation and break up of cartels.

The estimates in this paper show that cartels are more likely to be formed when firms perceive that their business has evolved positively in the previous months. Further cartels are also less likely to collapse when firms perceive that their business has evolved positively and when they expect prices to decline. These results lend support to pro-cyclical collusion theoretical predictions.

As we previously noticed, the findings of this study, as with any other study based on discovered cartel data, may be subject to selection bias when the sample of discovered cartels is not representative of the total cartel population (discovered and undiscovered cartels). Regarding this question, Harrington and Chang (2009) build a dynamic game-theoretic model that endogenizes both cartel birth and death to evaluate the impact of various competition policies on the cartel population by 


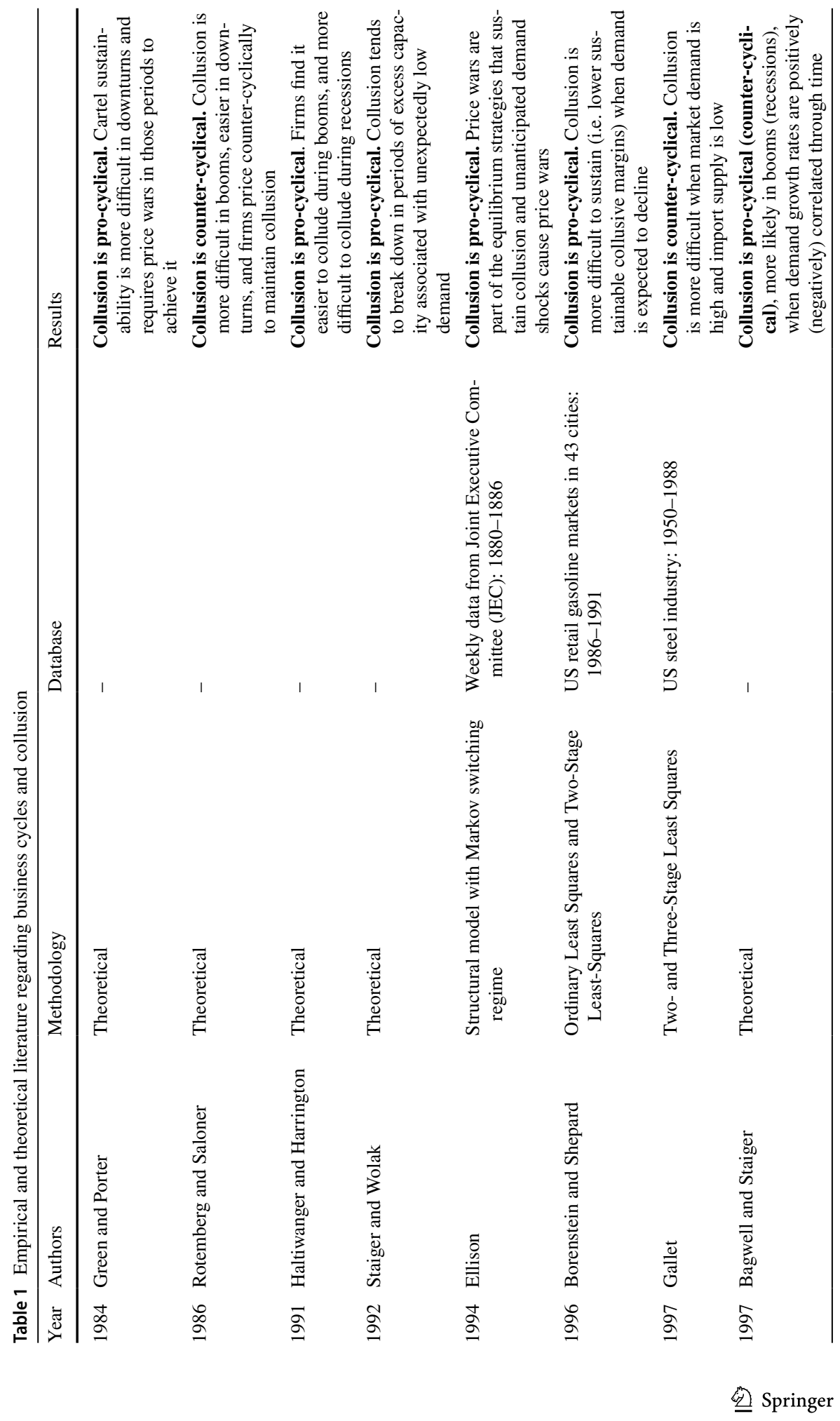




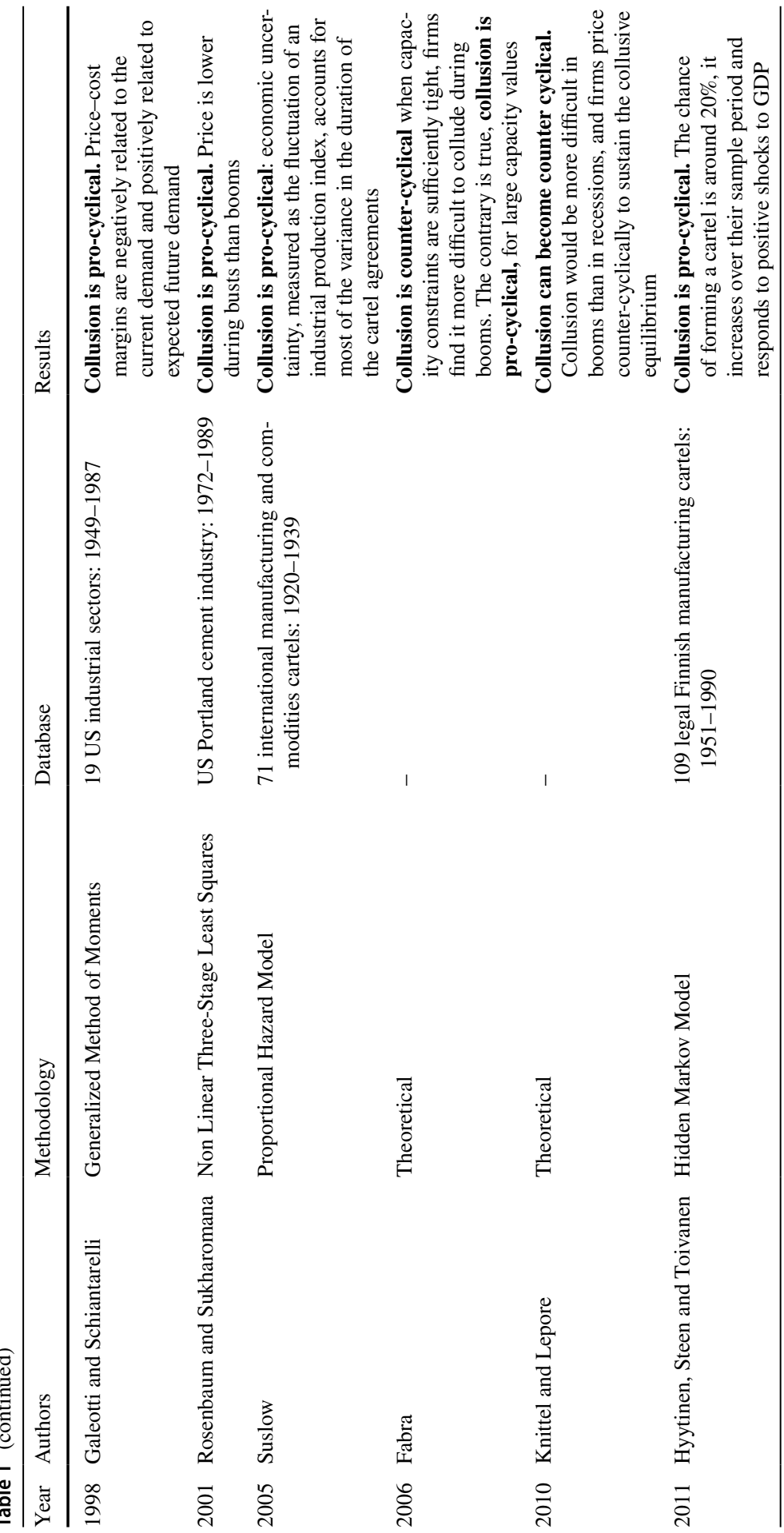




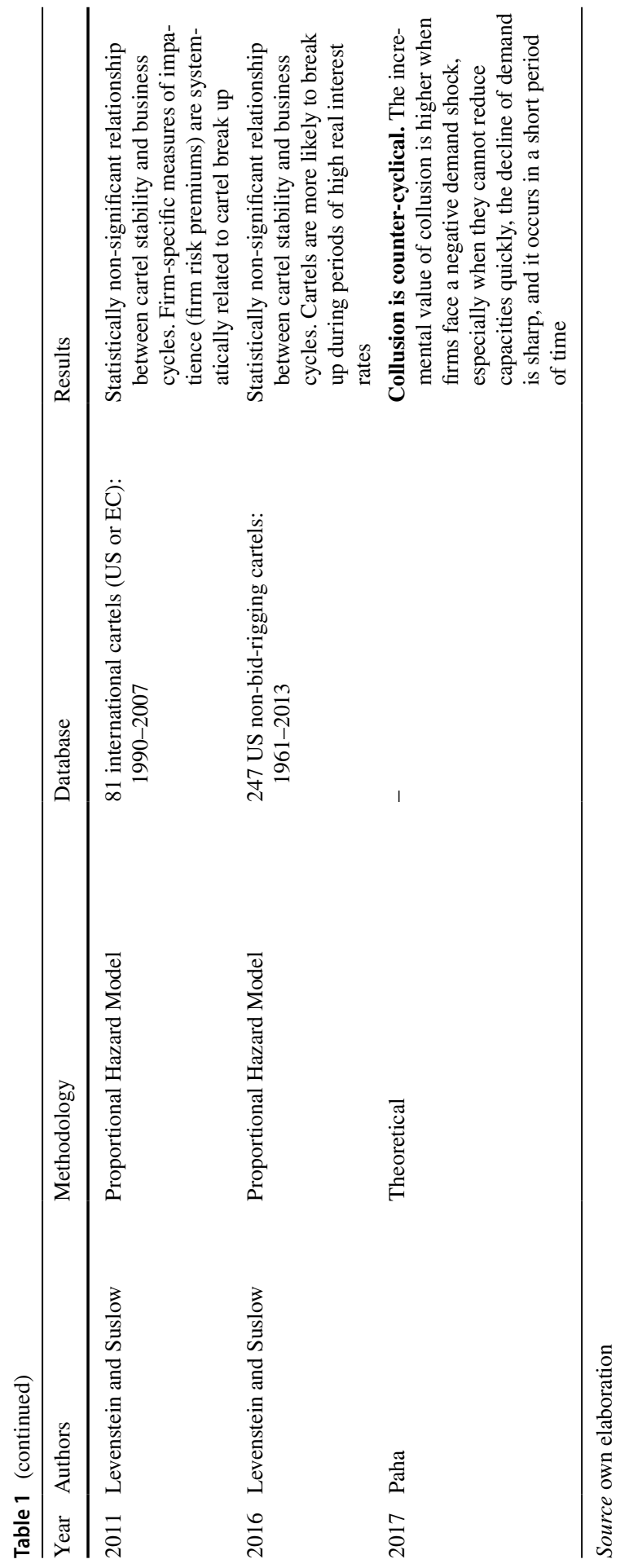


measuring its impact on the population of discovered cartels. They conclude that the duration of discovered cartels may provide some information about the underlying number of cartels. ${ }^{12}$ Harrington and Wei (2017) investigate the selection bias when using the duration of discovered cartels to infer the duration of all cartels (discovered and undiscovered). They find that when all cartels have the same probabilities of collapse and discovery, the average duration of discovered cartels is an unbiased measure of average cartel duration. However, when the probability of collapse and discovery varies across cartels, they show that a bias may exist.

Based on the Harrington and Wei (2017) analysis, we will briefly discuss below how our results might be affected by our sample's selection bias. On the basis that cartels are heterogeneous in the probability of collapse and discovery, let us consider the issue of the effect of business cycles on the break up of cartels. If all the internally collapsing cartels are discovered, which would be more likely with the leniency program in place, ${ }^{13}$ then our estimates would most likely be unbiased. The sample of cartels that collapse internally obtained from discovered cartels is actually the universe of all cartels that collapse for internal reasons. But if not all the cartels that collapse internally are discovered, our results would be biased. For instance, if only cartels that collapse as a result of being more exposed to economic cycles are discovered but not those cartels that collapse internally for reasons other than the business cycle, then our results would be an overestimate of business cycles' effects on cartel break up. On the contrary, if only (or most) cartels that collapse internally for reasons other than the business cycle are discovered, but not all (or most) cartels that collapse internally do so because of business cycles, then our results regarding discovered cartels would be an underestimate of the true effect on the unknown underlying cartel population.

\section{Data}

The dataset has been constructed from the EC's decisions on cartel cases between 1969 and 2018. The EC has sanctioned 151 cartel cases over this period. Most of these cartels were discovered due to investigations initiated by the Commission's own initiative or following complaints by third parties (75 cartel cases); and the other 76 cartel cases have been detected under the EU Leniency Program since it was established in 1996.

From the EC's published decisions, we obtained information regarding cartels' formation and break up date. The former corresponds to the first moment for which

\footnotetext{
12 Harrington and Chang (2015) consider an extension of their previous model by introducing a leniency program and endogenizing non-leniency enforcement to assess how both means of enforcement interact and affect the cartel rate. Their results suggest that a leniency program should be accompanied by a severe sanctioning policy to enhance its deterrence effect on cartel formation and thus reduce the number of cartels.

13 As Harrington and Wei (2017) point out, and as shown in Harrington and Chang (2015), if leniency is full and firms do not anticipate colluding again, applying for leniency is a dominant strategy and, therefore, all collapsing cartels are discovered.
} 
the authority has evidence of a collusive agreement, which is usually a date before the starting date of the investigation. The latter is the moment in which the cartel breaks up.

In this paper, we analyze the likelihood of two different events across time (months): (1) the event of a cartel in the manufacturing industry ${ }^{14}$ in the EU in any month from January 1997 to December 2018 according to the EC files of sanctioned cartels; (2) the event of a cartel break up in the manufacturing industry in the EU in any month from January 1997 to December 2018 according to the EC files of sanctioned cartels. We also double-check whether the introduction of the leniency program in 1996 changed the impact of economic cycles on cartel formation and break up using evidence of the previous pre-leniency period from January 1991 to December $1996 .^{15}$

When studying cartel break ups, we restrict the empirical analysis to the cartels where break ups were for internal reasons. We qualify a cartel break up as due to "internal reasons" whenever the cartel break up date precedes the date at which the investigation started, and also all the cases that start by a leniency application. ${ }^{16}$

Recall that cartel investigations may begin via four ways: (1) the Commission's own initiative (ex-officio), (2) third party complaint, (3) after a cartel member notification during the pre-2004 regime in which agreements among firms had to be notified and could be authorized by the Commission (when they were not authorized, a cartel investigation could also be launched), (4) after one or more cartel member(s) notified their participation in a cartel and applied for lenient sanctioning treatment under the leniency program; available from 1996 onwards.

We only focus on cases in which the break up is for internal reasons because we are interested in analyzing firms' behavior regarding cartel activities by taking into account their appraisal about the business cycle: firms' perceptions of past business evolution, firms' sale price expectations, and EU real production cycles. We leave for further investigation the question of what the drivers of cartels break ups are when there is an external action, such as an EC investigation triggered by its own initiative (with or without having denied an agreement authorization), after a third party complaint, or when the break up occurs sometime after one of the cartel members applies for the leniency program.

We have also computed the date of the final decision adopted by the EC to create a variable called sanctioned cartels (the number of cartels sanctioned every month), which will control for the potential destabilizing effect of EC cartel law enforcement on existing cartels, and its deterrent effect on cartels that would not yet have formed.

We restrict the empirical analysis to the manufacturing industry sector (sector $\mathrm{C}$ in the NACE Rev. 2 classification) because it is the only sector for which we

\footnotetext{
14 Due to data limitations, the extended analysis that includes more sectors is performed in the Robustness Check section.

15 The time series of business evolution and price expectations starts in January 1985, while the series of production index at European level starts in January 1991. This is the reason why our pre-leniency sample only goes back to January 1991.

${ }^{16}$ In this case, we consider the date of the event that happened first: either the break up or the leniency application.
} 
have information for the whole period of analysis for all the independent variables (i.e., business evolution, price expectations and the production index). ${ }^{17}$ Although we are unable to exploit the fact that more industries outside of manufacturing are cartelized due to the unavailability of either business surveys or economic data, we do not consider this to be a major problem for two reasons.

First, 118 out of the 151 total cartel cases sanctioned between 1969 and 2018 by the EC that we use to construct our dataset pertain to the manufacturing sector $(78 \%) .{ }^{18}$ As shown in Table 2, 89 out of 122 cartels sanctioned between 1991 and 2018 - the whole time period of the pre- and post-leniency program used below in our estimates-belong to the manufacturing sector (73\%). Additionally, 86 out of 110 cartels sanctioned in the post-leniency program period from 1997 to 2018 pertain to the manufacturing industry $(78 \%)$.

In addition, 62 out of the 118 cartel cases in the manufacturing sector have been discovered under the leniency program $(52.5 \%),{ }^{19}$ which means that the firms cooperate with the EC and therefore, the date of formation reflects on average more closely the start of the collusive agreement. ${ }^{20}$

On the other hand, if we look at the EU-28's non-financial business economy at the NACE section level, the manufacturing sector comprises a wide variety of activities. It includes a vast range of activities and production techniques, from smallscale enterprises using traditional production techniques, to very large enterprises sitting atop a high and broad pyramid of parts and component suppliers collectively manufacturing complex products. Additionally, around $8.9 \%$ of all enterprises belong to the manufacturing industry. Moreover, within the EU-28's non-financial business economy, in 2018, manufacturing was the second largest sector in terms of its contribution to employment $(23.1 \%)$ and the largest contributor to 'value added' $(29.7 \%) .{ }^{21}$ Given the significance of the manufacturing sector in the EU, it is important to focus on this industry. Moreover, as Levenstein and Suslow (2014) argue, there are some industries that seem particularly prone to collusion activity. Specifically, they cited those characterized by high fixed costs; as in the manufacturing sector. $^{22}$

As Table 2 shows, 66 out of 86 cartels from the manufacturing industry sanctioned by the EC after 1997 broke up for internal reasons; not as a result of a targeted

\footnotetext{
17 There are some sectors for which we have information, but insufficient data to perform the full analysis. The baseline regressions include other sectors that will be presented in the robustness check section.

18 Sorting the sectors by number of cases discovered, the manufacturing sector is followed by the transportation and storage sector (sector $\mathrm{H}$ ), which has 14 cases $(9.27 \%)$.

19 In 76 out of the 151 cartel cases considered (50.33\%), EC investigations were initiated following applications for leniency.

${ }^{20}$ Currently, 29 of the 34 cases for which we analyze cartel formation, and 59 out of the 66 cartels for which we study break up in the period 1997-2018, were discovered under the leniency program $(85.29 \%$ of those formed and $89.39 \%$ of those broken up).

21 Source: Eurostat.

22 Antonielli and Mariniello (2014) provide a ranking of European manufacturing sectors according to their risk of collusion, based on several structural features already highlighted in the economic literature. They find that EC interventions were consistent with their indicators related to the level of market concentration and economic rents, or economies of scale.
} 
investigation initiated by the Commission's own initiative or following a complaint. 59 of those 66 were initially investigated using the leniency program, so the leniency application of one cartelist enabled the Commission to initiate an investigation: 40 of them broke up before the leniency application, while 19 of them broke up after the leniency application. The other seven out of 66 broke apart before the Commission started the investigation by its own initiative or third-party complaint, not using the leniency program. Finally, only 34 (discovered) cartels were formed after January 1997. Table 2 also shows that most of the cartels sanctioned pertain to the manufacturing industry; particularly in the 1997 to 2018 period.

The variables we model are denoted as formed cartels and broken cartels. The former tells us the number of (discovered) cartels that were formed each month ${ }^{23}$ from the database in the manufacturing sector. The latter is the number of (discovered) cartels in the manufacturing sector that were broken up for internal reasons in each month of the period studied. As explained above, we include all the cartels that collapsed for internal causes: they had broken up before they were discovered by the Commission or a third party, and also those that broke up because one or more of the member(s) applied for leniency. In the latter case, we use the date of the application as the break up date if the application occurred before the collusive agreement completely collapsed, as leniency applications are noticed and the data shows that it does not take long to completely collapse.

As summarized in Table 3, the variable regarding monthly cartel formation takes value from 0 to 3 , while that of monthly cartel break up takes value from 0 to 4 . The variable sanctioned cartels $^{24}$ takes value from 0 to 6 , which means that up to 6 cartels were sanctioned in the same month by the EC.

Figure 1 depicts all three variables over time for the manufacturing sector. As we focus on the cartels sanctioned between January 1997 and December 2018 that were simultaneously formed in that time span, the figure shows that sanctioned cartels were predominantly formed in the first half of the period under study. By contrast, the figure shows that sanctioned cartels break up throughout the period under study, since many of them were formed before 1997.

As noted above, we introduce a novel approach with regard to the related literature by considering business managers' expectations. The variables business evolution and price expectations were obtained from the Business and Consumer Surveys, which is a harmonized survey managed by the EC's Directorate-General for Economic and Financial Affairs. ${ }^{25}$ The data consists of monthly time series according

\footnotetext{
23 Brenner (2009) also analyzes time series data on discovered cartels by the European Commission.

24 This variable includes the cartels sanctioned by the EC every month in all sectors, since the discovery of a relevant cartel in another sector may increase the deterrent and destabilizing effects of the Commission's activity on an unrelated sector. Results are robust to considering only cartel cases sanctioned in the manufacturing sector.

25 The Joint Harmonised EU Programme of Business and Consumer Surveys, User Guide, 2016. Source: https://ec.europa.eu/economy_finance/db_indicators/surveys/documents/bcs_user_guide_en.pdf
} 
Table 2 Summary of cartel cases sanctioned by the European Commission (1991-1996 and 1997-2018) (and \% of cartel cases belonging to the manufacturing sector)

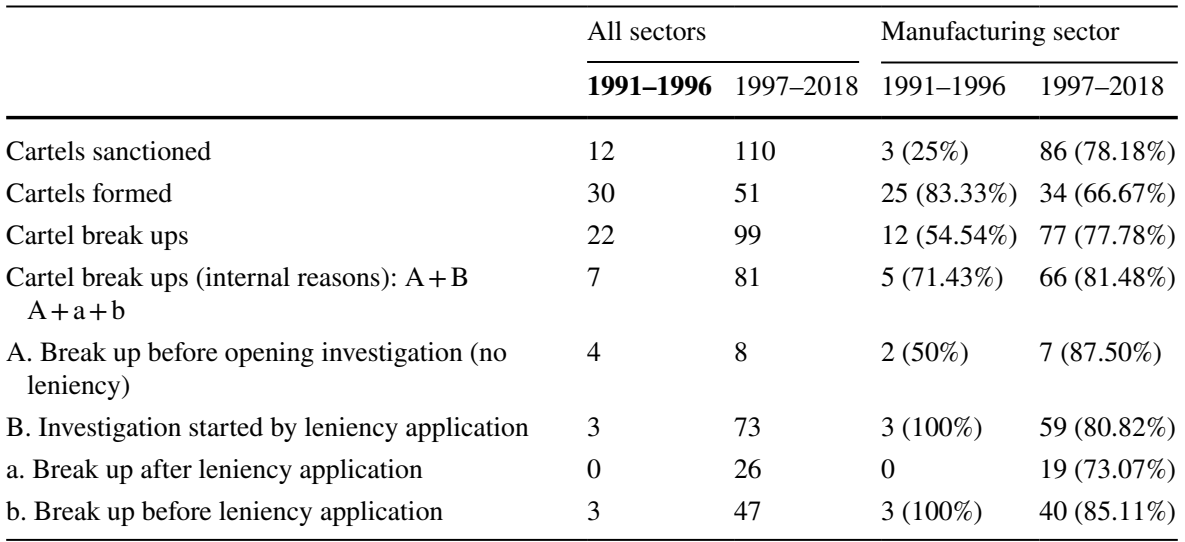

Further information regarding the nature of these cartels can be found in Ordóñez-de-Haro et al. (2018) Source Own elaboration from EC publicly available decisions

to the Classification of economic activities in the European Community (NACE) at sector level. ${ }^{26}$

According to Taylor and McNabb (2007), the business confidence indicator is pro-cyclical, and it can generally predict movements in GDP over the business cycle and downturns.

Since the process of forming a cartel takes some time, we use the survey variable on price expectations instead of the current price, as the decision to engage in a cartel today could be more affected by price expectations in the future than by current price levels.

Both variables are indices, ${ }^{27}$ and they correspond respectively to the questions "how has your production developed over the past three months?" and "how do you expect your selling price to change over the next three months?" The surveys are conducted at firm level, and then the data is classified and aggregated by stratum (i.e., by sector) and countries, using adequate weights. ${ }^{28}$ The geographical coverage of the surveys includes all Member States as well as the candidate countries, although we only use Member States results. The harmonized surveys are carried out at national level by national institutes and offices. The sample size for each survey varies across countries according to the heterogeneity of their economies and their population size. The sample of the industry survey includes more

\footnotetext{
26 Additionally, the Business Survey presents the data at a more aggregated level. In particular, they divide the NACE sectors into five main categories: industry, construction, retail trade, service sector and financial services. This classification is the one we use for our analysis.

27 The data of the Business and Consumer Survey is at EU level.

28 See footnote 28. Further information about data treatment can be found in the Methodological User Guide.
} 
Table 3 Summary statistics (1997-2018)

\begin{tabular}{llcccc}
\hline Variable & $\mathrm{N}$ & Mean & Std. Dev & Min & Max \\
\hline Formed cartels & 264 & 0.129 & 0.41 & 0 & 3 \\
Broken up cartels for internal reasons & 264 & 0.178 & 0.50 & 0 & 4 \\
Business evolution & 264 & 2.434 & 10.87 & -47.6 & 20.4 \\
Price expectations & 264 & 4.739 & 7.15 & -14.1 & 22.6 \\
Sanctioned cartels & 264 & 0.417 & 0.76 & 0 & 6 \\
Production EU & 264 & 99.33 & 9.75 & 62.8 & 115.4 \\
Production growth rate (-1) & 264 & 0.009 & 0.13 & -0.29 & 0.43 \\
Production growth rate (-12) & 264 & 0.015 & 0.05 & -0.22 & 0.10 \\
\hline
\end{tabular}

Manufacturing sector

Source Author's computations from EC publicly available decisions and the Business Survey. Manufacturing sector only
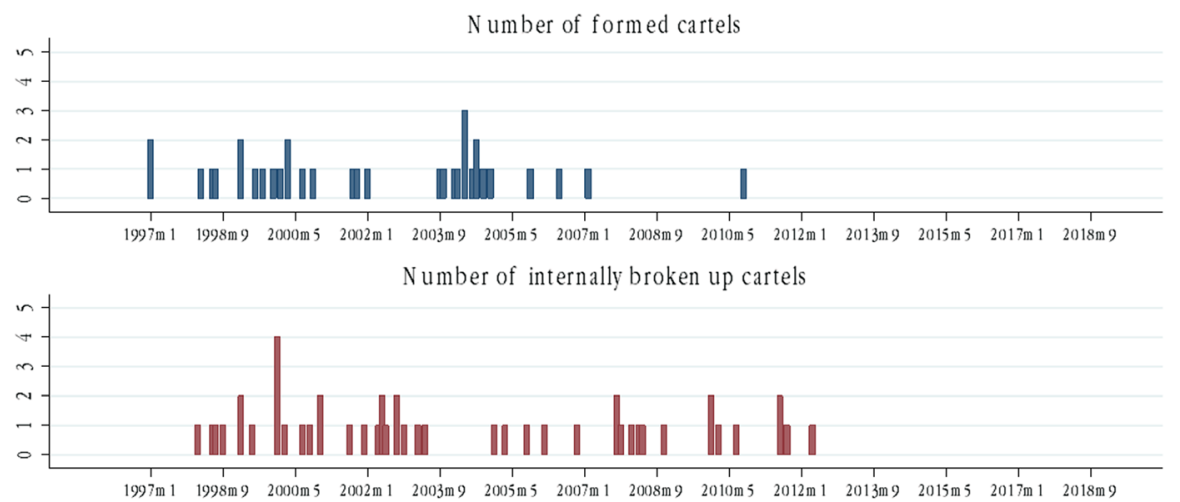

$\mathrm{N}$ umber of sanctioned cartels

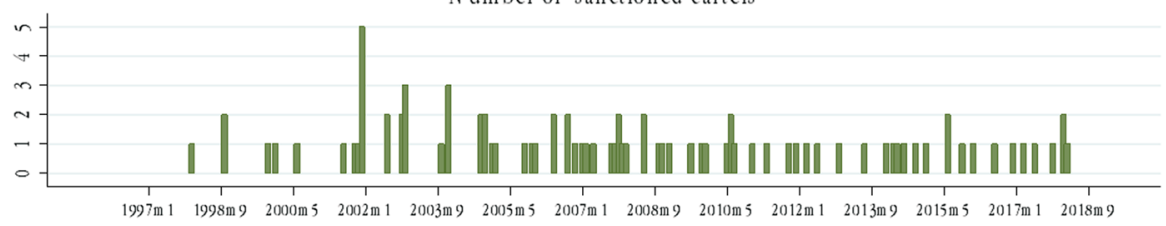

Fig. 1 Number of monthly formed, sanctioned and 'broken up for internal reasons' cartels in the manufacturing sector (1997-2018). Source Own elaboration from EC publicly available decisions

than 38,000 units that are surveyed every month, in the first two to three weeks of each month. The industry survey is largely qualitative.

The survey's questions of interest for our study admit three possible responses: increase, remain unchanged and decrease. Answers obtained from the surveys are aggregated in the form of balances, which are constructed as the difference in the percentage of positive and negative answers. The information provided allows the use of a range of variables to monitor cyclical dynamics. 
We have used non-seasonally adjusted data for business evolution, price expectations, and production EU. The variable production EU has been obtained from Eurostat. The time series corresponds to monthly data of the volume index of production in the corresponding sector, at European level (EU19) and where 2015=100. The variable production growth rate accounts for the growth rate of the variable production $E U$, with respect to the previous month or the previous year, depending on the model specification. The descriptive statistics of these variables for the manufacturing sector are shown in Table 3.

\section{Empirical strategy}

As mentioned above, we analyze managers' perceptions about the evolution of their business and expectations they have regarding sale price, and also the effect of industry production on the dependent variables of interest. Our empirical strategy uses Poisson model estimations, given that the dependent variable is a count variable. Even the value zero has a positive probability of occurrence in both cases (formed and broken up cartels).

The basic Poisson model assumes that $y$ given $x$ has a Poisson distribution, and the density of $y$ given $x$ is completely determined by the conditional mean. Another assumption imposed by Poisson distribution is that the conditional variance is equal to the conditional mean. Nevertheless, even if there is over-dispersion in the data, according to Cameron and Trivedi (2009) the Poisson panel estimators rely on weaker distributional assumptions than the negative binomial model, so that it would be more robust to use the Poisson panel estimators with cluster-robust standard errors to resolve the usual over-dispersion. ${ }^{29}$

It should be noted that working with information regarding cartels means that only characteristics of the uncovered cartels are observed. Therefore, if the variables formed or broken up cartels take the value of zero, it could be because no cartel was formed or broken up that specific month, or because it was formed or broken up, but hasn't been discovered. Unfortunately, we cannot distinguish between these two types of selection, as is also the case in the Zero Inflated Poisson (ZIP) regression. However, this model tries to capture which are the relevant variables that cause the count to be zero. Therefore, we have also worked with this alternative model specification, but results are not shown in the paper since the Vuong (1989) test ${ }^{30}$ of ZIP vs Poisson does not favor the former model.

In sum, the equation of the full model estimated in order to analyze the relationship between formed cartels and expectations is ${ }^{31}$ :

$\log \left(\mathrm{E}\left(\right.\right.$ formed_cartels $\left.\left._{t} \mid x\right)\right)=\beta_{0}+\beta_{1}$ bu $\sin$ ess_evolution ${ }_{t}+\beta_{2}$ price_expectations $_{t}+$

$\beta_{3}$ sanctioned_cartels $+\beta_{4}$ production_EU $U_{t}+\beta_{5}$ production_growth_rate ${ }_{t-i}$

\footnotetext{
${ }^{29}$ We have tested if there exists over-dispersion in the data and whether the Negative Binomial model would best fit the data, but the results rule out this possibility.

${ }^{30}$ It tests the null hypothesis that the two models fit the data equally well.

${ }^{31}$ The error term does not appear in equation [1] because the model is expressed in terms of the conditional expectation.
} 
where $x$ denotes the vector of independent variables. ${ }^{32}$ We estimate different specifications of the model by gradually introducing the explanatory variables.

Regarding the estimation of the equation to explain why cartels break up internally, the empirical strategy is the same as in equation [1], but substituting the variable of formed cartels by broken up cartels as a dependent variable.

$\log \left(\mathrm{E}\left(\right.\right.$ broken_cartels $\left.\left._{t} \mid x\right)\right)=\beta_{0}+\beta_{1}$ bu $\sin$ ess_evolution ${ }_{t}+\beta_{2}$ price_expectations $_{t}+$

$\beta_{3}$ sanctioned_cartels $+\beta_{4}$ production_EU $U_{t}+\beta_{5}$ production_growth_rate ${ }_{t-i}$

As previously mentioned, we will gradually introduce covariates in both estimations in order to control for different effects by groups of exogenous variables. The results are presented in the following section.

\section{Results}

The results of the Poisson regression model for equation [1] are shown in Table 4. As stated above, we have considered alternative specifications of the model. Note that the standard errors have been corrected using the Newey-West estimator in order to overcome potential problems of autocorrelation and heteroskedasticity. The results shown in the table are the point estimates of the beta coefficients. ${ }^{33}$

First, we can see how- regardless of model specification-the managers' perceptions of the evolution of the firm's business in the last three months positively and significantly affect the number of cartels formed. An increase of the business evolution index in one unit will increase the average number of formed cartels by around $3.6-4.8 \%$. This suggests that cartel formation is strongly pro-cyclical with respect to firm growth: the likelihood of cartel formation is related to firm growth in the near past.

Secondly, the other variable of interest, price expectations, has no impact on the formation of cartels. Thus, we find no evidence that managers take into account the expectations they have of price evolution when forming a cartel.

It is also notable that the number of total sanctioned cartels (in manufacturing and other industries) in the same period negatively influences cartels formation. Since the EC's decision is public, seeing that more cartels are being sanctioned seems to be an effective deterrent because it could increase the perceived probability of being caught.

Finally, results show that the effect of the industry real production index at EU level negatively and significantly affects cartel formation in most specifications. This reflects weak evidence that the pro-cyclicality of cartel formation and firm-specific business cycle is less strong when sector production is low. In addition, the effect of the variables considering production growth in the sector on cartel formation is positive; increasing the pro-cyclical effect of industry production on cartel formation.

\footnotetext{
${ }^{32}$ In equations [1] and [2], the subindex $i$ takes on value 1 or 12, depending on the model.

33 They tell us that a one unit increase in the independent variable will increase the average number of the dependent variable by $ß$ percent.
} 
If the variables business evolution or price expectations are both affected by cartel formation (i.e., endogenous), our estimates might be biased. We should remember that the estimated coefficient is equal to the true value of the coefficient, plus the bias. As usual, the sign and magnitude of this bias depend on the underlying correlation between the corresponding explanatory variable and the residual of Poisson regression of cartel formation; that is, the unobserved component of cartel formation.

A larger amount of cartel formation might be anticipated as increasing pricing (and markups) but decreasing business activity. Therefore, business activity might eventually be negatively correlated with the residuals in the Poisson regression. In this case, our estimate might be downward biased. As we find a positive effect of business activity on cartel formation, this coefficient might be even larger, and the sign of the true effect remains positive. Again, this is showing evidence of pro-cyclical collusion.

As noted above, more cartel formation might be anticipated as increasing pricing and markups. So, price expectations might eventually be positively correlated with the residuals in the Poisson regression of cartel formation. In this case, our estimate might be upward biased. As we find a non-significant effect of price expectations on cartel formation, the true effect might eventually be negative. And, again, with endogenous price expectations we might again find evidence of pro-cyclical collusion.

In our results for the post-leniency period, the business evolution has a positive effect on cartel formation. Therefore, in this baseline model, what matters most for cartel formation is the perception that business people have about the evolution of their own production, while sector production also affects the decision to cartelize or not.

Empirical results regarding cartel formation appear to show that collusion is procyclical with respect to a firm-specific business cycle. These results are robust to those obtained in the strand of the theoretical literature started by the seminal paper of Bagwell and Staiger (1997) and Haltiwanger and Harrington (1991), who showed that it is easier to collude during booms and more difficult during recessions, and in the case of non-binding capacity constraints studied by Fabra (2006).

Table 5 presents the results of the estimations of Eq. (2) concerning the explanatory variables of the break up of cartels.

Contrary to Eq. (1), both managers' appraisal of past production and selling price expectations significantly affect the break up of cartels for internal reasons in the manufacturing sector. Managers' perceptions of the evolution of the firm's business in the previous months negatively affect cartel break up; reducing the average number of cartel break ups by $1.7-5.4 \%$.

This result is in line with that obtained in the case of cartel formation: when the production of an individual firm has evolved positively in the previous months it is more likely to form a cartel, and if the firms are already in a cartel, then it is also easier to sustain collusion since it is less likely that a cartel breaks up. This represents evidence of pro-cyclical collusion with respect to cartel break ups when economic cycles are measured using firm-specific business evolution. 
Table 4 Poisson estimation results: formed cartels in the manufacturing sector (1997-2018)

\begin{tabular}{lllll}
\hline & $(1)$ & $(2)$ & $(3)$ & $(4)$ \\
\hline Business evolution & $0.040^{* * *}$ & $0.036^{* * *}$ & $0.038^{* * *}$ & $0.048^{* * *}$ \\
Price expectations & $(0.011)$ & $(0.011)$ & $(0.015)$ & $(0.018)$ \\
Production EU & -0.002 & 0.000 & 0.012 & 0.003 \\
& $(0.018)$ & $(0.017)$ & $(0.017)$ & $(0.015)$ \\
Sanctioned cartels & $-0.031^{* *}$ & -0.024 & $-0.050^{* *}$ & $-0.028^{* * *}$ \\
& $(0.014)$ & $(0.015)$ & $(0.026)$ & $(0.012)$ \\
Production growth rate & & $-0.626^{* * *}$ & $-0.544 * * *$ & $-0.615 * * *$ \\
& & $(0.148)$ & $(0.137)$ & $(0.139)$ \\
Constant & & & $3.141 * * *$ & -3.387 \\
Observations & 0.798 & 0.318 & $(1.394)$ & $(4.642)$ \\
Chi2 & $(0.964)$ & $(1.011)$ & 2.610 & 0.650 \\
p-value & 264 & 264 & $(1.941)$ & $(0.819)$ \\
\hline
\end{tabular}

$* \mathrm{p}<0.10, * * \mathrm{p}<0.05, * * * \mathrm{p}<0.01$ significance test. Newey-West standard errors within brackets. Model (3) controls for production growth rate with respect to previous month and model (4) with respect to previous year

Moreover, the number of cartels broken up appears to also be related with the level of prices expected by firms' managers, and with the number of sanctioned cartels in the same or previous months. The higher the prices are expected to be at the beginning of the month for the next three months, the higher the number of cartels broken up that month. The effect of an increase of one unit in price expectations is that the break up of cartels is increased by between 3.8 and $5.0 \%$. On the other hand, collusion is more likely when firms expect a decline in prices in the near future.

Regarding the level of production, no significant impact is found on cartel break up, while production growth rates have a significant effect on cartel break up. Additionally, Levenstein and Suslow's (2011) study of cartel break up found that fluctuations in firm-specific discount rates have a significant effect on cartel duration, whereas market interest rates do not. Also, other cartel organization features are relevant in explaining cartel duration.

Finally, the number of sanctioned cartels in all sectors also affects cartel break up in the manufacturing sector. The higher the number of sanctioned cartels, the higher the number of broken up cartels. This can be interpreted as an indirect destabilizing effect of the EC's sanctioning decisions that causes the collapse of other cartels not targeted by these decisions, thus law enforcement on detected cartels also negatively affects the stability of previously undetected cartels.

Again, we should consider that our estimates might be biased if business evolution/price expectations are affected by cartel break up. Following the same logic as in the previous discussion, more cartel break up might be anticipated as reducing pricing (and markups), and also expanding business. If anticipated, 
Table 5 Poisson estimation results. Internally broken up cartels in the manufacturing sector (1997-2018)

\begin{tabular}{lllll}
\hline & $(1)$ & $(2)$ & $(3)$ & $(4)$ \\
\hline Business evolution & $-0.019^{* *}$ & $-0.019^{* * *}$ & $-0.017^{* *}$ & $-0.054^{* * *}$ \\
Price expectations & $(0.009)$ & $(0.009)$ & $(0.008)$ & $(0.015)$ \\
Production EU & $0.046^{* * *}$ & $0.046^{* * *}$ & $0.050^{* * *}$ & $0.038^{* *}$ \\
& $(0.017)$ & $(0.017)$ & $(0.016)$ & $(0.018)$ \\
Sanctioned cartels & -0.011 & -0.012 & $-0.029^{*}$ & 0.004 \\
& $(0.011)$ & $(0.011)$ & $(0.016)$ & $(0.010)$ \\
Production growth rate & & $0.089 * *$ & $0.122^{* *}$ & $0.094^{*}$ \\
Constant & & $(0.043)$ & $(0.051)$ & $(0.049)$ \\
& & & $1.934 * * *$ & $9.246^{* * *}$ \\
Observations & -0.850 & -0.773 & $(0.685)$ & $(2.613)$ \\
Chi2 & $(0.908)$ & $(0.916)$ & 0.695 & $-1.638^{* *}$ \\
p-value & 264 & 264 & $(1.355)$ & $(0.819)$ \\
\hline
\end{tabular}

$* \mathrm{p}<0.10, * * \mathrm{p}<0.05, * * * \mathrm{p}<0.01$ significance test. Newey-West standard errors in brackets. Model (3) controls for production growth rate with respect to the previous month and model (4) with respect to the previous year

business evolution might eventually be positively correlated with the residuals of the break up regression, and our estimate might be upward biased. As we estimate a negative coefficient for the impact of business evolution on cartel break up, this negative coefficient might even be larger than estimated, but the estimated sign remains negative, signaling pro-cyclical collusion.

Regarding price expectations, as this might be negatively correlated to the residuals of the break up regression, our estimate might be downward biased. As we find a significant and positive coefficient for the impact of price expectations on cartel break up, this effect might be even larger than estimated, and the sign of the true effect remains positive. Again, even with endogenous price expectations, there is evidence of pro-cyclical collusion.

In sum, all these results combined tell us that there are asymmetries in the effect of economic cycles on cartel formation and break up: if the firm is doing well in terms of their own production, then firms will get involved in a cartel to make larger profits (pro-cyclical cartel formation). On the other hand, if the firm is not doing well in terms of the evolution of their production and managers expect their sale price to increase in the following periods, the likelihood of cartel collapse is higher. 


\section{Robustness checks}

In this section, we check whether our results are robust to the inclusion of more sectors. The reason why we include this test as a robustness check is that due to data limitations, we cannot perform all the desired analyses on the sample formed by several sectors.

Next, we analyze to what extent the relationship between economic cycles and collusion has remained stable in the post-leniency period (1997-2018) with respect to the pre-leniency period (1991-1996) in the EU. Finally, we assess the relationship between business cycles and various relevant dates in the EC's cartel case decisionmaking process; specifically, the dates on which it decides to initiate investigations, start proceedings and adopt the sanctioning decision, in order to understand the economic conditions under which the EC makes decisions, and to rule out any identification problem of the estimated relationship between cartel formation/break up and business cycles.

\subsection{Inclusion of additional sectors}

We check whether our results hold when we include a number of other sectors (i.e., manufacturing; construction; wholesale and retail trade; transportation and storage $)^{34}$ in our specifications to introduce more variability. We will see that results hold in the case of cartel formation, while we obtain some non-significant effects in the case of cartel break up.

Collusion activity in the manufacturing sector is followed by the transportation and storage sector (sector $\mathrm{H}$ ), which has 14 cartel cases. This sector focuses on transport services provided to clients for 'hire and reward'. There were more than 1.2 million enterprises in the EU-28's transportation and storage services sector in 2018, equivalent to $5.3 \%$ of the non-financial business economy. The sector employed 10.3 million people in 2018 and accounted for $8.0 \%$ of the wealth generated in the non-financial business economy.

The wholesale trade sector (Sector G) had eight cartel cases sanctioned. By most measures, the wholesale trade sector was one of the largest sectors within the EU-28's non-financial business economic. In 2018, its enterprises accounted for $25.4 \%$ of all non-financial business economy enterprises, generated the largest value in turnover $(34.1 \%)$ and employment in that sector accounted for $22.6 \%$ of the non-financial business economy. The construction sector (Sector F) registered three sanctioned cartel cases during the whole period. This sector is one of the smallest (at the NACE division level) within the EU-28's non-financial business economy. In 2018 , its enterprises, which account for $3.6 \%$ of the total number of enterprises in the EU, employed $2.4 \%$ of the non-financial business economy workforce, and generated $2.1 \%$ of the value added (of the non-financial business economy).

\footnotetext{
34 Sectors C, F, G \& H, respectively, in NACE Rev.2 classification. Note that the choice of sectors arises from data availability restrictions. For the same reason, we cannot include these sectors in the analysis of the pre-leniency period.
} 


\subsubsection{Cartel start-up}

As explained above, we start by showing the results of the inclusion of additional sectors in the main regressions of cartel formation. Results are shown in Table 6. First note that the conclusions obtained from Table 4 still hold: business evolution affects cartel formation positively and significantly and price expectations do not affect cartel formation. Also, production negatively affects cartel formation. Similarly, regarding the manufacturing sector, the evidence is weak that the pro-cyclicality of cartel formation and the firm-specific business cycle is less strong when sector production is low.

\subsubsection{Cartel break up}

We follow the same procedure used for the robustness check of cartel formation for the case of cartel break up. We estimate the Poisson model including more sectors to check the robustness of the results obtained in the baseline model.

The models presented in Table 7 are less informative than the baseline case considered in Table 5. Neither the variable business evolution nor the variable price expectations have any significant effect on cartel break up. However, the sector production has a negative and significant impact on cartel break up in this case, while the positive impact of sanctioned cartels on cartel break up is maintained. So, our pro-cyclical collusion estimates seems to be sounder and more precise in the manufacturing sector, but not so when we include other sectors.

\subsection{Pre-leniency program period}

So far, we have only analyzed the cartel cases formed or broken up in the manufacturing sector during the period January 1997 to December 2018. However, both the formation and break up of these cartels have been affected by the existence of the leniency program, which was introduced in July 1996 by the European Union.

This program may produce two opposite effects in the dynamics of cartels birth and death. On the one hand, members of a discovered cartel case can benefit from a fine reduction under certain circumstances. Therefore, the ex-ante profits from collusion are higher than in the case in which the sanctioned firm has to pay the full fine, for a given probability of detection, which means that the likelihood of cartel formation increases. On the other hand, the incentives to deviate and break up the cartel are higher under the leniency program, since the first member(s) revealing the existence of the illegal collusive agreement could receive a higher or even a full fine reduction. Thus, we should see that the probability of a break up is greater. ${ }^{35}$

In sum, the introduction of the leniency program may have affected the way in which the independent variables affect our dependent variables of interest. For this reason, we focus in this section on the period from January 1991 to December

\footnotetext{
35 A more detailed analysis on leniency programs' destabilization effects can be found in Borrell et al (2021).
} 
Table 6 Poisson estimation results. Formed cartels (1997-2018)

\begin{tabular}{lllll}
\hline & $(1)$ & $(2)$ & $(3)$ & $(4)$ \\
\hline Business evolution & $0.073^{* * *}$ & $0.070^{* * *}$ & $0.075^{* * *}$ & $0.069^{* * *}$ \\
Price expectations & $(0.026)$ & $(0.026)$ & $(0.028)$ & $(0.023)$ \\
Production EU & -0.009 & -0.006 & -0.000 & -0.008 \\
& $(0.025)$ & $(0.025)$ & $(0.027)$ & $(0.028)$ \\
Sanctioned cartels & $-0.065^{* * *}$ & $-0.060^{* * *}$ & $-0.089^{* * *}$ & $-0.059^{* * *}$ \\
& $(0.013)$ & $(0.013)$ & $(0.017)$ & $(0.009)$ \\
Production growth rate & & $-0.495^{* *}$ & $-0.447^{* * *}$ & $-0.495^{* *}$ \\
Constant & & $(0.202)$ & $(0.171)$ & $(0.361)$ \\
& & & $4.740^{* * *}$ & 1.185 \\
Observations & $3.027^{* * *}$ & $2.731^{* * *}$ & $(1.006)$ & $(6.863)$ \\
Pseudo-R & $(0.561)$ & $(0.585)$ & $5.407^{* * *}$ & $2.633^{* * *}$ \\
\hline
\end{tabular}

Sectors C, F, G and $\mathrm{H}$

$* \mathrm{p}<0.10, * * \mathrm{p}<0.05, * * * \mathrm{p}<0.01$ significance test. Cluster standard errors by sector within brackets. Model (3) controls for production growth rate with respect to previous month and model (4) with respect to previous year

1996. ${ }^{36}$ Following the methodology outlined in Sect. 4, we will study how business evolution, price expectations, sanctioned cartels and production at European level affected the formation and break up of cartels during this period.

Table 2 shows how the number of cartels formed in the period 1991-1996 (30 cartels) is lower than the number of cartels formed after 1997 (51 cartels), while the number of broken up and internally broken up cartels is also significantly lower in the period 1991-1996 (22 and seven respectively) than in the period 1997-2018 (99 and 81 respectively).

Figure 2 illustrates the formation, breakup and sanction distribution of the discovered cartels over the whole time period 1959 to 2018 . The number of internally broken up cartels grows exponentially from 1997, and the number of sanctioned cartels clearly increases from 1997 onwards.

We estimate the same equations as before, now for the cartels start-ups and break ups between 1991 and 1996, in the pre-leniency period using the monthly data described in Table 8.

In Table 9 we can see the results of the Poisson model estimation of cartel formation, and in Table 10 the results of cartel break up.

For the period before the leniency program (1991-1996), we find that collusion seems to be weakly counter-cyclical when looking at cartel formation from the industry-wide cycles perspective, while collusion also appears to be

${ }_{36}$ Manufacturing is the only sector for which we have information for the period 1991-1996. 
Table 7 Poisson estimation results

(1)

Business evolution

Business evolution

Price expectations

Production EU

Sanctioned cartels

Production growth rate

Constant

Observations

Pseudo-R2
(2)

0.024
$(0.024)$

0.031

$(0.029)$

$-0.053 * *$

(0.021)

0.025
$(0.024)$

0.030

(0.029)

$-0.055^{* *}$

(0.021)

$0.160 * * *$

(0.054)
(3)

0.032

(0.027)

0.030

(0.029)

$-0.082 * * *$

$(0.029)$

$0.189 * * *$

(0.044)

$4.327 * * *$

(1.521)

$4.887 * *$

(2.166)

897

0.089
(4)

0.022

$(0.024)$

0.026

(0.030)

0.160 ***

2.272

2.163

886

0.059

Broken up cartels (1997-2018)

Sectors C, F, G and $\mathrm{H}$

$* \mathrm{p}<0.10, * * \mathrm{p}<0.05, * * * \mathrm{p}<0.01$ significance test. Cluster standard errors by sector within brackets. Model (3) controls for production growth rate with respect to previous month and model (4) with respect to previous year

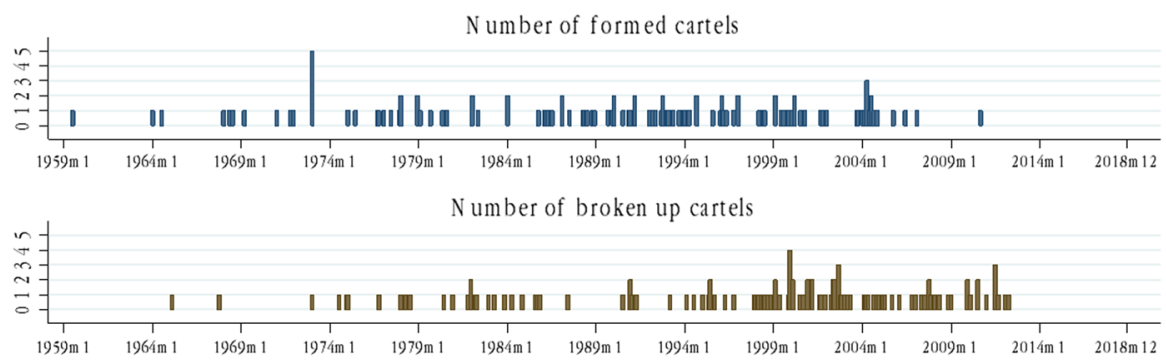

$\mathrm{N}$ umber of internally broken up cartels

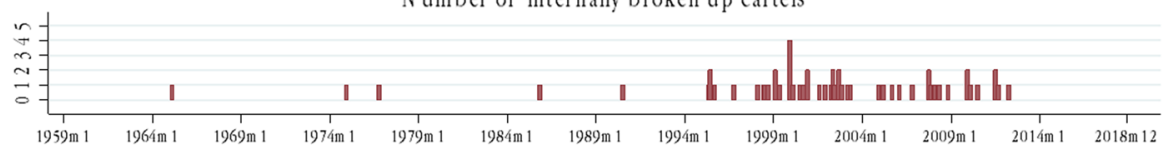

$\mathrm{N}$ umber of sanctioned cartels

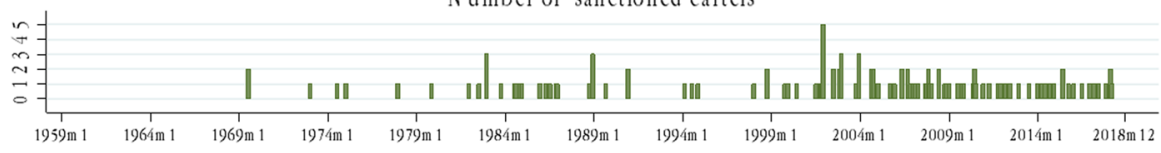

Fig. 2 Number of monthly formed, broken up, sanctioned and broken up for internal reasons cartels in the manufacturing sector (1959-2018). Source Own elaboration from EC publicly available decisions 
Table 8 Summary statistics (1991-1996)

\begin{tabular}{lccccc}
\hline Variable & $\mathrm{N}$ & Mean & Std. Dev & Min & Max \\
\hline Formed cartels & 72 & 0.347 & 0.59 & 0 & 2 \\
Broken up cartels for internal reasons & 72 & 0.069 & 0.31 & 0 & 2 \\
Business evolution & 72 & -4.490 & 10.40 & -26.7 & 16.7 \\
Price expectations & 72 & 8.084 & 8.37 & -4 & 31.1 \\
Sanctioned cartels & 72 & 0.167 & 0.38 & 0 & 1 \\
Production EU & 72 & 77.923 & 7.86 & 52.1 & 86.7 \\
Production growth rate $(-1)$ & 71 & 0.013 & 0.17 & -0.3 & 0.5 \\
Production growth rate $(-12)$ & 60 & 0.003 & 0.04 & -0.08 & 0.09 \\
\hline
\end{tabular}

Source Own elaboration from EC publicly available decisions and the Business Survey. Manufacturing sector only

Table 9 Poisson estimation results

\begin{tabular}{lllll}
\hline & $(1)$ & $(2)$ & $(3)$ & $(4)$ \\
\hline Business evolution & $-0.027^{* *}$ & $-0.031^{* * *}$ & $-0.036^{* *}$ & $-0.118^{*}$ \\
Price expectations & $(0.013)$ & $(0.014)$ & $(0.014)$ & $(0.065)$ \\
& -0.010 & -0.005 & 0.015 & -0.015 \\
Production EU & $(0.012)$ & $(0.013)$ & $(0.020)$ & $(0.011)$ \\
& 0.026 & 0.031 & -0.005 & 0.048 \\
Sanctioned cartels & $(0.027)$ & $(0.025)$ & $(0.027)$ & $(0.031)$ \\
& & $-0.878^{* * *}$ & $-0.690 * *$ & $-1.460^{* *}$ \\
Production growth rate & & $(0.308)$ & $(0.325)$ & $(0.700)$ \\
& & & $2.424^{* * *}$ & 25.257 \\
Constant & & & $(0.352)$ & $(17.372)$ \\
& & -3.550 & -1.033 & $-4.987^{*}$ \\
Observations & $(2.267)$ & $(2.179)$ & $(2.400)$ & $(2.631)$ \\
Chi2 & 72 & 72 & 71 & 60 \\
p-value & 2.226 & 3.617 & 8.274 & 5.689 \\
\hline
\end{tabular}

Formed cartels in the manufacturing sector (1991-1996)

$* \mathrm{p}<0.10, * * \mathrm{p}<0.05, * * * \mathrm{p}<0.01$ significance test. Newey-West standard errors within brackets. Model (3) controls for production growth rate with respect to previous month and model (4) with respect to previous year

counter-cyclical when looking at cartel break up from both the firm-specific business cycle and now the economic sector too.

However, in the pre-leniency period, the drivers of cartel formation and break up are different with respect to the post-leniency period. The driver of cartel formation in the pre-leniency period is firm-level business evolution and price expectations with negative signs (Table 9), while the drivers of cartel formation 
Table 10 Poisson estimation results

\begin{tabular}{lllll}
\hline & $(1)$ & $(2)$ & $(5)$ & $(6)$ \\
\hline Business evolution & $0.368^{* * *}$ & $0.390^{* * *}$ & $0.479 * * *$ & $0.452^{* * *}$ \\
Price expectations & $(0.036)$ & $(0.056)$ & $(0.064)$ & $(0.036)$ \\
Production EU & $-0.208^{* * *}$ & $-0.216^{* * *}$ & $-0.283^{* * * *}$ & $-0.195 * * *$ \\
& $(0.018)$ & $(0.022)$ & $(0.028)$ & $(0.031)$ \\
Sanctioned cartels & $0.461^{* * *}$ & $0.449 * * *$ & $0.509 * * *$ & $0.354^{* * *}$ \\
& $(0.087)$ & $(0.080)$ & $(0.072)$ & $(0.066)$ \\
Production growth rate & & 0.441 & -0.024 & 0.545 \\
& & $(0.414)$ & $(0.339)$ & $(0.439)$ \\
Constant & & & $-2.582 * * *$ & $-24.949 *$ \\
& & & $(0.668)$ & $(14.253)$ \\
Observations & $-40.913 * * *$ & $-40.079^{* * *}$ & $-44.746 * * *$ & $-31.916 * * *$ \\
Chi2 & $(7.509)$ & $(6.926)$ & $(6.217)$ & $(5.873)$ \\
p-value & 72 & 72 & 71 & 60 \\
\hline
\end{tabular}

Internally broken up cartels in the manufacturing sector (1991-1996)

$* \mathrm{p}<0.10, * * \mathrm{p}<0.05, * * * \mathrm{p}<0.01$ significance test. Newey-West standard errors within brackets. Model (3) controls for production growth rate with respect to previous month and model (4) with respect to previous year

in the post-leniency period are firm-level business evolution (with positive sign), and industry-wide production at the EU level (Table 4).

The drivers of cartel break up in the pre-leniency period ${ }^{37}$ seem to be mostly business evolution and price expectations at firm level (Table 10) and also EU industry real production, while in the post-leniency period EU industry real production is not significant. Note that this last statement should be considered carefully, given that the number of cartels broken up in the manufacturing sector for internal reasons are very low during the period January 1991-December 1996.

\subsection{The cyclical nature of the EC's decisions in cartel sanctioning procedures}

In this section we analyze the relationship between sanctioned cartels and various economic indicators, in order to understand the economic conditions under which the EC makes decisions. Previous results show that the EC's sanctioning activity has a deterrent effect on cartel formation, and also a positive spillover effect on previously undetected cartels' break up. Additionally, we have seen that the industry real production has no effect or a weak negative effect on cartel break up.

\footnotetext{
37 We double-checked, as previously, whether these results for the pre-leniency period were robust to the presence of endogeneity of price expectations, and we found that they are indeed robust. Results from these robustness checks are available on request from the authors.
} 
However, it is also relevant to understand whether the EC devotes more resources to investigating, prosecuting and punishing cartels in downturns, which would increase the likelihood of internal break up of the cartel in order to apply for the leniency program before it is discovered by the EC. Therefore, we study the effect of industry real production on the number of sanctioned cartels, the number of cartel investigations and proceedings initiated. The results are presented in Table 11 (Sanctioned cartels), Table 12 (Number of investigations initiated) and Table 13 (Number of proceedings initiated). ${ }^{38}$

These estimation results point to the lack of relationship between industry production and its growth rate with the number of cartels sanctioned, while some effects are found in the number of investigations and in the number of proceedings initiated by the EC. Our estimates suggest that the EC devotes more resources to initiating investigations and proceedings in cartel cases during economic downturns. This finding does not appear to support theories of softer enforcement of anti-cartel law by competition authorities during economic downturns, and to highlight the fact that EC authorities are 'walking the walk and not just talking the talk' when they emphasize that anti-cartel enforcement should not be compromised regardless of economic conditions (Stephan, 2012).

Our result is also in line with Ghosal and Gallo's (2001) finding of the counter-cyclical nature of the US Department of Justice's antitrust enforcement activity, which they interpret as a consequence of an increase in antitrust violations during economic downturns. However, in the EC's antitrust activity context, taking into account our previous results, one more plausible explanation is that the number of cartels internally broken up increases during economic recessions. This in turn, with the leniency program in force, would bring about more leniency applications to the EC with a subsequent increase in the number of cartel cases initiated.

Therefore, it is very important that the EC continues to adequately resource its DG Competition for cartel cases during periods of economic contractions. In this way, the EC's sanctioning activity would be guaranteed and, according to our results, its sanctioning decisions would have potential deterrent effects on cartel formation, as well as the corresponding destabilizing effects that would accelerate the breaking up of existing cartels.

\section{Conclusions}

In this paper we focus both on cartel formation and break ups, and how these two events are determined not only by a firm's recent demand, production level and the industry's economic context, but also by the expectations that firm managers have. To address this issue, we study the number of cartels formed and the number of cartels broken up for internal reasons in the EU each month, mostly after the introduction of the leniency program 1997-2018, but also during the pre-leniency period, from 1991 to 1996.

$\overline{38}$ The estimations considering only sector $\mathrm{C}$ yield similar qualitative results. 
Table 11 Poisson estimation results

Table 12 Poisson estimation results

\begin{tabular}{llll}
\hline & $(1)$ & $(2)$ & $(3)$ \\
\hline Business evolution & 0.014 & 0.017 & 0.015 \\
& $(0.014)$ & $(0.016)$ & $(0.013)$ \\
Price expectations & 0.025 & 0.024 & 0.024 \\
& $(0.026)$ & $(0.026)$ & $(0.026)$ \\
ProductionEU19 & -0.024 & -0.034 & -0.025 \\
& $(0.022)$ & $(0.030)$ & $(0.021)$ \\
Production growth rate & & 1.864 & -0.072 \\
& & $(1.547)$ & $(5.420)$ \\
Constant & 0.120 & 1.054 & 0.167 \\
& $(1.715)$ & $(2.432)$ & 625 \\
Observations & 898 & 897 & 886 \\
Pseudo-R & & 0.028 & 0.023 \\
\hline
\end{tabular}

Sanctioned cartels (1997-2018)

Sectors C, F, G and H

$* \mathrm{p}<0.10, * * \mathrm{p}<0.05, * * * \mathrm{p}<0.01$ significance test. Model (2) controls for production growth rate with respect to previous month and model (3) with respect to previous year

\begin{tabular}{llll}
\hline & $(1)$ & $(2)$ & $(3)$ \\
\hline Business evolution & 0.009 & 0.015 & 0.009 \\
& $(0.023)$ & $(0.025)$ & $(0.025)$ \\
Price expectations & 0.037 & 0.036 & 0.036 \\
& $(0.031)$ & $(0.033)$ & $(0.029)$ \\
ProductionEU19 & $-0.055 * * *$ & $-0.075 * * *$ & $-0.056 * * *$ \\
Production Growth Rate & $(0.015)$ & $(0.021)$ & $(0.016)$ \\
& & $3.075 * * *$ & 0.187 \\
Constant & & $(1.074)$ & $(2.708)$ \\
& $2.953 * * *$ & $4.863 * * *$ & $2.998 * * *$ \\
Observations & $(0.931)$ & $(1.472)$ & $(0.979)$ \\
Pseudo-R & 898 & 897 & 886 \\
\hline
\end{tabular}

Number of investigations initiated (1997-2018)

Sectors $\mathrm{C}, \mathrm{F}, \mathrm{G}$ and $\mathrm{H}$

$* \mathrm{p}<0.10, * * \mathrm{p}<0.05, * * * \mathrm{p}<0.01$ significance test. Model (2) controls for production growth rate with respect to previous month and model (3) with respect to previous year

Specifically, by estimating a Poisson regression model, we analyze the effect of sector real production (industry growth or decline), of business evolution 
Table 13 Poisson estimation results

\begin{tabular}{llll}
\hline & $(1)$ & $(2)$ & $(3)$ \\
\hline Business evolution & 0.014 & 0.019 & 0.022 \\
& $(0.015)$ & $(0.018)$ & $(0.016)$ \\
Price expectations & 0.012 & 0.010 & 0.017 \\
& $(0.021)$ & $(0.020)$ & $(0.020)$ \\
ProductionEU19 & $-0.039^{*}$ & $-0.056^{*}$ & $-0.041^{*}$ \\
Production growth rate & $(0.023)$ & $(0.029)$ & $(0.023)$ \\
& & $2.925^{* * *}$ & $-4.272^{* *}$ \\
Constant & & $(1.094)$ & $(2.128)$ \\
& 1.608 & 3.245 & 1.802 \\
Observations & $(1.597)$ & $(2.224)$ & $(1.614)$ \\
Pseudo- ${ }^{2}$ & 898 & 897 & 886 \\
\hline
\end{tabular}

Number of proceedings initiated (1997-2018)

Sectors C, F, G and $\mathrm{H}$

$* \mathrm{p}<0.10, * * \mathrm{p}<0.05, * * * \mathrm{p}<0.01$ significance test. Model (2) controls for production growth rate with respect to previous month and model (3) with respect to previous year

perceptions in previous months (firm-perceived market dynamics) and the managers' price expectations on the likelihood of forming or breaking up a cartel.

Our results show that the average number of cartels formed increases when firmlevel perceived business income has evolved positively in the previous three months. It is also notable that the EC's sanctioning activity in cartel cases is an effective deterrent tool. Finally, results show that the effect of the industry real production index at EU level negatively and significantly affects cartel formation in most of the specifications. This reflects weak evidence that the pro-cyclicality of cartel formation and firm-specific business cycle is less strong when sector production is low. In addition, the effect of the variables considering production growth in the sector on cartel formation is negative; reducing the pro-cyclical effect of the industry production on cartel formation.

Regarding cartel break up, we find that cartels are more likely to collapse when a business has evolved negatively in the previous months, and when managers expect prices to increase. Furthermore, the EC's sanctioning activity represents a destabilizing effect that has a positive impact on breaking up cartels.

These results should be considered as a first approach to address the question under study as there is some scarcity of data and we are therefore having to rely on the time series of cartel start-ups, cartel break ups, cartels sanctioned and a set of business cycle variables. Ideally, the missing data problem should be overcome by working with panel data that includes more industries and territorial units.

New theoretical analysis should also be developed in line with that of Fabra (2006), Knittel and Lepore (2010), and Paha (2017), as the results we have obtained are consistent with the conclusion that collusion might be pro-cyclical when there are no capacity constraints. Firms find it easier to collude during booms; while 
collusion is counter-cyclical when capacity constraints are sufficiently tight or firms find it more difficult to collude during booms as they cannot reduce capacities quickly. It might be the case that capacity constraints are on average not binding in industries that are still not colluding (i.e., prior to a possible collusion), so demand booms are driving the start-up of cartels. After the cartels begin to function, collusion might be the driver not only of price hikes but also of coordinated reductions in the colluding industries' capacities. As capacity constraints get tight, collusion might become counter-cyclical, and cartels might finally break up also during booms.

In addition, important further research would be the study, from a theoretical and empirical point of view, of the determinants and characteristics that make some cartels attract the attention of the Antitrust Authority while others do not. Finally, the impact of successive reforms of the EC's leniency program on this issue also merits some further research.

Acknowledgements We would like to thank David K. Levine, Andrea Galeotti, Giacomo Calzolari, Juan-José Ganuza, Gerard Llobet and an anonymous referee for helpful suggestions and comments. The usual disclaimer applies. José Manuel Ordóñezde-Haro acknowledges financial support from the Junta de Andalucía-FEDER through projects UMA18-FEDERJA-243 and P18-FR-3840, and from the Spanish Ministry of Science, Innovation and Universities through project RTI2018-097620-B-I00. Joan-Ramon Borrell thanks the unconditional research grants received from the Catalan Government (SGR2017-644), the Spanish Government (PID2019-104319RB-I00), and the European Commission (611585-EPP-1-2019-1-ES-EPPJMO-NETWORK).

Funding Open Access funding provided thanks to the CRUE-CSIC agreement with Springer Nature.

Open Access This article is licensed under a Creative Commons Attribution 4.0 International License, which permits use, sharing, adaptation, distribution and reproduction in any medium or format, as long as you give appropriate credit to the original author(s) and the source, provide a link to the Creative Commons licence, and indicate if changes were made. The images or other third party material in this article are included in the article's Creative Commons licence, unless indicated otherwise in a credit line to the material. If material is not included in the article's Creative Commons licence and your intended use is not permitted by statutory regulation or exceeds the permitted use, you will need to obtain permission directly from the copyright holder. To view a copy of this licence, visit http://creativecommons.org/licen ses/by/4.0/.

\section{References}

Antonielli, M., \& Mariniello, M. (2014). Antitrust Risk in EU Manufacturing: A Sector-Level Ranking. Bruegel Working Paper, 2014/07.

Athey, S., \& Bagwell, K. (2001). Optimal collusion with private information. The RAND Journal of Economics, 32(3), 428-465.

Athey, S., \& Bagwell, K. (2008). Collusion with persistent cost shocks. Econometrica, 76(3), 493-540.

Bagwell, K., \& Staiger, R. W. (1997). Collusion over the business cycle. The RAND Journal of Economics, 28(1), 82-106.

Besanko, D., \& Doraszelski, U. (2004). Capacity dynamics and endogenous asymmetries in firm size. The RAND Journal of Economics, 35(1), 23-49.

Bils, M. (1987). The cyclical behavior of marginal cost and price. American Economic Review, 77, 838-855.

Borenstein, S., \& Shepard, A. (1996). Dynamic pricing in retail gasoline markets. The RAND Journal of Economics, 27(3), 429-451. 
Borrell, J.R., García, C., Jiménez J.L. and Ordóñez-de-Haro, J.M. (2018). Cartel destabilization effect of leniency programs, In García Galindo, C. Essays on cartels and competition policy. European University Institute, PhD Thesis. Department of Economics. http://hdl.handle.net/1814/59224, https:// doi.org/10.2870/13080.

Brenner, B. (2009). An empirical study of the European corporate leniency program. International Journal of Industrial Organization, 27(6), 638-645.

Cameron, A. C., \& Trivedi, P. K. (2009). Microeconometrics using Stata. Stata Press Publication.

Domowitz, I., Hubbard, R. G., \& Petersen, B. C. (1986a). Business cycles and the relationship between concentration and price-cost margins. The RAND Journal of Economics, 17(1), 1-17.

Domowitz, I., Hubbard, R. G., \& Petersen, B. C. (1986b). The intertemporal stability of the concentration-margins relationship. Journal of Industrial Economics, 35, 13-34.

Domowitz, I., Hubbard, R. G., \& Petersen, B. C. (1988). Market structure and cyclical fluctuations in manufacturing. The Review of Economics and Statistics, 70(1), 55-66.

Ellison, G. (1994). Theories of cartel stability and the joint executive committee. The RAND Journal of Economics, 25(1), 37-57.

Fabra, N. (2006). Collusion with capacity constraints over the business cycle. International Journal of Industrial Organization, 24(1), 69-81.

Fershtman, C., \& Pakes, A. (2000). A dynamic oligopoly with collusion and price wars. The RAND Journal of Economics, 31(2), 207-236.

Galeotti, M., \& Schiantarelli, F. (1998). The cyclicality of markups in a model with adjustment costs: Econometric evidence for US industry. Oxford Bulletin of Economics and Statistics, 60(2), 121-142.

Gallet, C. A. (1997). Cyclical fluctuations and coordination in the US steel industry. Applied Economics, 29(3), 279-285.

Ghosal, V., \& Gallo, J. (2001). The cyclical behavior of the Department of Justice's antitrust enforcement activity. International Journal of Industrial Organization, 19(1-2), 27-54.

Green, E. J., \& Porter, R. H. (1984). Noncooperative collusion under imperfect price information. Econometrica, 52(1), 87-100.

Haltiwanger, J., \& Harrington, J. E. (1991). The impact of cyclical demand movements on collusive behavior. The RAND Journal of Economics, 22(1), 89-106.

Harrington, J. E. (2008). Detecting cartels. In P. Buccirossi (Ed.), Handbook of antitrust economics (pp. 213-258). MIT Press.

Harrington, J. E., \& Chang, M. H. (2009). Modeling the birth and death of cartels with an application to evaluating competition policy. Journal of the European Economic Association, 7(6), 1400-1435.

Harrington, J. E., \& Chang, M. H. (2015). When can we expect a corporate leniency program to result in fewer cartels? The Journal of Law and Economics, 58(2), 417-449.

Harrington, J. E., \& Wei, Y. (2017). What can the duration of discovered cartels tell us about the duration of all cartels? Economic Journal, 127(604), 1977-2005.

Hyytinen, A., Steen, F., \& Toivanen, O. (2011). Cartels uncovered. American Economic Journal: Microeconomics, 10(4), 190-222.

Knittel, C. R., \& Lepore, J. J. (2010). Tacit collusion in the presence of cyclical demand and endogenous capacity levels. International Journal of Industrial Organization, 28(2), 131-144.

Levenstein, M., \& Suslow, V. Y. (2006). What determines cartel success? Journal of Economic Literature, 44, 43-95.

Levenstein, M., \& Suslow, V. Y. (2011). Breaking up is hard to do: Determinants of cartel duration. Journal of Law and Economics, 54(2), 455-492.

Levenstein, M., \& Suslow, V. Y. (2014). Cartels and collusion: Empirical evidence. In R. D. Blair \& D. D. Sokol (Eds.), The Oxford handbook of international antitrust economics. (Vol. 2). Oxford University Press.

Levenstein, M., \& Suslow, V. Y. (2016). Price fixing hits home: An empirical study of US price-fixing conspiracies. Review of Industrial Organization, 48, 361-379.

Ordóñez-de-Haro, J. M., Borrell, J. R., \& Jiménez, J. L. (2018). European Commission's fight against cartels (1962-2014): A retrospective and forensic analysis. Journal of Common Market Studies, 56(5), 1087-1107.

Paha, J. (2017). The value of collusion with endogenous capacity and demand uncertainty. Journal of Industrial Economics, 65(3), 623-653.

Perdiguero, J. (2010). Dynamic pricing in the Spanish Gasoline Market: A tacit collusion equilibrium. Energy Policy, 38, 1931-1937. 
Porter, R. H. (1983). A study of cartel stability: The joint executive committee, 1880-1886. The Bell Journal of Economics, 14(2), 301-314.

Rosenbaum, D., \& Sukharomana, S. (2001). Oligopolistic pricing over the deterministic market demand cycle: Some evidence from the US portland cement industry. International Journal of Industrial Organization, 19(6), 863-884.

Rotemberg, J. J., \& Saloner, G. (1986). A Supergame-theoretic model of price wars during booms. The American Economic Review, 76(3), 390-407.

Rotemberg, J. J., \& Woodford, M. (1991). Markups and the business cycle. NBER Macroeconomics Annual, 6, 63-140.

Simpson, S. S., \& Rorie, M. (2016). Economic Fluctuations and Crises. The Oxford handbook of whitecollar crime (pp. 326-344). Oxford University Press.

Staiger, R., \& Wolak, F. (1992). Collusive pricing with capacity constraints in the presence of demand uncertainty. The RAND Journal of Economics, 23(2), 203-220.

Stephan, A. (2012). Price fixing in crisis: Implications of an economic downturn for cartels and enforcement. World Competition, 35(3), 511-528.

Stigler, G. (1964). A theory of oligopoly. Journal of Political Economy, 72(1), 44-61.

Suslow, V. Y. (2005). Cartel contract duration: Empirical evidence from inter-war international cartels. Industrial and Corporate Change, 14(5), 705-744.

Taylor, K., \& Mcnabb, R. (2007). Business cycles and the role of confidence: Evidence for Europe. Oxford Bulletin of Economics and Statistics, 69(2), 185-208.

Tirole, J. (1988). The theory of industrial organization. MIT Press.

Vuong, Q. (1989). Likelihood ratio tests for model selection and non-nested hypotheses. Econometrica, 57(2), 307-333.

Publisher's Note Springer Nature remains neutral with regard to jurisdictional claims in published maps and institutional affiliations.

\section{Authors and Affiliations}

\section{Carmen García ${ }^{1}$ (D) Joan Ramon Borrell ${ }^{2,3}$ (D) . José Manuel Ordóñez-de-Haro ${ }^{4} \mathbb{D}$. Juan Luis Jiménez ${ }^{1}$}

Joan Ramon Borrell

jrborrell@ub.edu

José Manuel Ordóñez-de-Haro

jmoh@uma.es

1 Universidad de Las Palmas de Gran Canaria, Las Palmas de Gran Canaria, Las Palmas, Spain

2 Universitat de Barcelona, Institut d'Economia Aplicada (IREA) - Grup de Governs i Mercats (GiM), Barcelona, Spain

3 Universityof Navarra, IESE Business School, Public-Private Sector Research Center, Barcelona, Spain

4 Universidad de Málaga, Dep. de Teoría e Historia Económica, Málaga, Spain 